удК

316.75:141.76(497.1)"1972/1991"(093.2)

141.76:061.2(497.1)"1972/1991"(093.2)

DOI https://doi.org/10.31212/tokovi.2020.3.rak.165-190

Оригинални научни рад

Примљен: 5. 7. 2020.

Прихваћен: 1. 10. 2020.

Aleksandar RAKOVIĆ

Institute for Recent History of Serbia, Belgrade

rakovic@gmail.com

\title{
Organizations and Activities of Yugoslav Naturists (1972-1991)*
}

\begin{abstract}
The paper presents the organization and activities of Yugoslav naturists, as well as their intention to play a social role in the field of physical and health culture, environmental protection, tourist propaganda, public defense and social self-protection in the socialist society from 1972 to 1991. Despite their ambitions, Yugoslav naturist societies, did not form an important social group or cultural movement.

KEY WORDS: Naturism, Socialism, Yugoslavia, Organization, Activity, Nudity
\end{abstract}

So far, neither Serbian nor Yugoslav historiography, nor post-Yugoslav historiographies, have written about the organizations of Yugoslav naturists. This topic has not been researched so far, nor has it been written about in other social-humanistic fields. In this regard, this paper presents, for the first time, the organization and activities of Yugoslav naturist societies from 1972 to 1991 based on the naturist press of the time, tourist periodicals, hotel and catering press, entertainment press, and archives of the Tourist Association of Yugoslavia kept in the Archives of Yugoslavia.

\section{Introduction}

The cradle of naturism is Germany. In Germany and in the German-speaking area of Austria and Switzerland, the naturist culture -

This paper is published as part of the project Serbs and Serbia in the Yugoslav and International Context: Development and Position in European/World Community (47027) funded by the Ministry of Education and Science of the Republic of Serbia. 
Freikörperkultur (FKK) or Nacktkultur - has grown into a movement and a philosophy of healthy living. At the end of the 19th century, some Germans, fleeing from industrialization, accepted the Lebensreform movement, which also meant a return to nature. Being naked in that natural environment in the air and in the sun was considered beneficial for physical and mental health, and at the same time a resistance to urbanization and materialism. ${ }^{1}$ It was initially a collection of different subcultures without too many common goals and without a common ideology. ${ }^{2}$ The "culture of nudity" in Germany, during the first four decades of the 20th century, was a network of nudist clubs in nature. ${ }^{3}$

The expansion of naturist culture could not have happened in closed clubs, but only through nudism on the sea beaches. The beaches in the cold seas and lukewarm lakes were not suitable for this. The first naturist beach in Germany was partially opened on the North Sea island of Sylt in 1919. After the World War II, the first naturist beach in the Federal Republic of Germany was fully opened in Grube on the Baltic Sea in 1959. ${ }^{4}$ Since 1970, more and more naturist beaches were opened on the seas and lakes in the FR of Germany. In the late 1970s, in one day alone, there were as many as 35,000 naturists on Lake Langen near Wiesbaden. ${ }^{5}$

However, the arrival of West German naturists to the warm seas of France and Yugoslavia, from the 1950s on, caused a rapid development and widespread of the naturist culture. In the early 1970s, the FR of Germany had about 700,000 naturist club members, usually including entire families. ${ }^{6}$ That was only a modest figure because it was estimated that there were as many as 8 million German nudists in the FR of Germany, most of them not being members of any associations. As for France, in the mid-1970s, it was estimated that there were as many as 4 million French nudists. ${ }^{7}$ During the 1980 s, between 1.5 and 2 million naturists

1 Brian Hoffman, Naked: a Cultural History of American Nudism, (New York: New York University Press, 2015), 1-3.

2 Karl Toepfer, Empire of Ecstasy. Nudity and Movement in German Body Culture, 19101935, (Berkeley: University of California Press, 1997), 30-32.

3 Ibid., 30-32.

4 Georg Pfitzner, Der Naturismus in Deutschland, Österreich und der Schweiz, Band 1, (Hamburg - Altona: Richard Danehl's Verlag, 1964), 39, 60.

5 Jerko Sladoljev, Naturistički kampovi i naselja. Povijest, koncepcija, razvoj, (Pula: CASH, 2001), 29.

6 Savo Marić, „Naturizam - nova šansa turizma“, Turizam 5/1972, 27-28.

7 „Goli osvajaju svet“, Duga, 3. septembar 1977. 
spent their summer vacations in French naturist centers and camps. Half of those nudists were French and half were foreign. ${ }^{8}$

In that triangle, crucial for the development of naturism in Europe - the FR of Germany, France, and Yugoslavia - the FR of Germany provided the largest number of naturists, France numerous naturist centers and large numbers of naturists, and Yugoslavia the largest number of naturist centers (and wild beaches), but the fewest naturists, which, in Yugoslav naturist organizations, were measured in the thousands.

The main naturist accommodation facilities in Yugoslavia were built during the seventies. Istria was at the forefront of this and in the late 1970s it had a capacity for 50,000 naturists on just 30 kilometers of coastline. ${ }^{9}$ Montenegroturist, which included Ada Bojana naturist camp, announced in its paper that in 1985, Yugoslavia had a total capacity of 53,000 places in 25 naturist resorts, camps, and hotels. This does not include naturists who came to about 40 organized naturist beaches and who knows how many wild beaches. ${ }^{10}$ In 1989 , Yugoslavia advertised its organized naturist facilities for about 60,000 guests. ${ }^{11}$

This would, for the more successful seasons of the 1970s, carry an estimate of about 250,000 naturists in July and August in organized facilities, probably up to 400,000 naturists with pre-season and post-season (April-June, September-October), and even more if naturists are taken into account who were located outside the naturist capacities. ${ }^{12}$ Naturism in Yugoslavia had a "strong growth" until the eighties, writes the Jadran from Rovinj in 1988 and adds, but "trends in the development of the movement subsided in the late 1980s and in the last 10 years we have only two newly opened naturist centers, while in the meantime two centers were partially closed or replaced naturist facilities with the usual camping activity." ${ }^{13}$ Such fears were also expressed by the Croatian Naturist Association, whose newspaper at the end of 1986 wrote that some naturist centers on the Adriatic either ceased to exist or opened their doors to "textiles" or guests in bathing suits. ${ }^{14}$

$8 \quad$ Stephen L. Harp. Au Naturel. Naturism, Nudism, and Tourism in Twentieth-Century France, (Baton Rouge: Louisiana State University Press, 2014), 2-4, 87.

9 „Sedmi međunarodni susret naturista Solaris 26-28 V 1978“, Naš glas, lipanj 1978.

10 „Izdašni poklonici Evinog kostima“, Montenegroturist, 25. 8. 1985.

11 Arhiv Jugoslavija (Archives of Yugoslavia - AJ), Tourist Association of Yugoslavia, Fond 746, Box 107, Catalog Camping '89 Jugoslavija, (Beograd: Turistički savez Jugoslavije, Auto-moto savez Jugoslavije, 1989).

12 Ibid.

13 „Naturizam, turizam, slobodno vrijeme“, Jadran, listopad 1988.

14 „Najveći regionalni okrugli stol o naturizmu“, Zdravo, No. 14, (Zagreb), 1987. 
In 1988, Dinko Tomašić, chairman of the Naturism Committee of the Group of Camping and Naturism at the General Board of the Tourist Economy of Yugoslavia, announced that about 321,300 naturists, mostly foreigners, had spent their summer holidays in 25 naturist settlements, camps and hotels in Yugoslavia had 3,052,340 overnight stays. However, despite the good business results, Tomašić said, "naturism has been declining in our country in recent years." ${ }^{15}$ When we take into account about 40 organized naturist beaches, with accommodation facilities in other places, and countless wild naturist beaches, it is possible that in the second half of the eighties, this would lead to a jump in the number of naturists in Yugoslavia to 400,000 and more. The exact number cannot be determined.

Based on such massive numbers of almost entirely foreign naturists, unrealistic estimates of the number of Yugoslav naturists were made. Turizam, the official journal of the Tourist Association of Croatia, states that in 1975, out of 36,000 members of the naturist movement in Yugoslavia, as many as 32,000 came from Slovenia. ${ }^{16}$ Duga wrote that in 1979 , as many as 100,000 Yugoslavs were prone to naturism and nudism. ${ }^{17}$ However, both of these assessments were extremely erroneous and without a basis in the facts.

Ilustrovana politika wrote that Yugoslav naturists were quite rare in the mid-1960s. ${ }^{18} \mathrm{~A}$ Zagreb naturist told a journalist at the Zagreb-based Vikend magazine in 1971 on the landscaped naturist beach of Cape Frkanj on the island of Rab, that since 1956, naturists had first gathered secretly at that place. Either the man from Zagreb completely identified with the first foreign naturists who came to Rab, or he was really among the first naturists, which would move the appearance of the first Yugoslav naturists to the second half of the fifties. ${ }^{19}$

This Zagreb naturist, almost in disbelief that there was such an explosion of naturism in Yugoslavia in the early seventies, tells the story of Rab: "Fifteen years ago, they threw stones at us. Bathing without swimsuits was kind of illegals under the warm Rab sun. We hid among the rocks like lepers. Sometimes they organized pursuits against us: as if in some martial arts movie, a handful of dressed swimmers would sneak through the undergrowth and pelt us with stones. Being a nudist almost meant carry-

15 „Naturizam treba negovati i propagirati“, Turističke novine, 15. 9. 1988.

16 Jelena Vugrinčić, „Naturizam kao mnogostruka pozitivna pojava“, Turizam 7-8 /1977, 39.

17 „Vreme golih”, Duga, 21. 6. 1980.

18 „Sve se vidi na Rabu“, Ilustrovana politika, 22. 7. 1969.

19 „Nudisti, tko ste vi?", Vikend, 13. 7. 1971. 
ing your head in a bag! The locals looked at us with disgust and mockingly call us 'nudies'. The pope thundered from his pulpit calling us messengers of the devil. Even the police were always after us, breaking us up."20

A doctor, assistant professor at the University of Belgrade, spent his vacation in 1970 with his wife in the largest Yugoslav naturist camp Koversada in Vrsar, which operated within the hotel and tourist company Anita. Under the alias Steva M. Ilijić, he wrote about it in the sequels for the Belgrade magazine Svet. ${ }^{21}$ In 1969, there were only 250 Yugoslav guests in that camp. ${ }^{22}$ Ilijić described the social life that his wife and he had in the camp and their communication with Western naturists. ${ }^{23}$ He said that it was a "high degree of emancipation and relief from various prejudices established for centuries." ${ }^{24}$ Ilijić thought that psychologists, psychiatrists, and psychoanalysts would have more affirmative attitudes toward the naked body if they spent fifteen days on a naturist beach. ${ }^{25}$

In Koversada none of the domestic naturists wanted to say their real names for an article in Duga in $1977 .^{26}$ In 1977, Montenegroturist journalists talked to a married couple from Zenica who were guests of the naturist camp on Ada Bojana, and the husband and wife did not want to introduce themselves or have their photos taken. However, they said: "People - aware that they are completely separated from civilization, surrounded by sea and river - somehow completely relax and unwind. Believe me, we had a better rest here in 10 days than if we had been in another resort for a full month."27 On Velika plaža near Ulcinj, one of the "wild" naturist gathering places, the naturists were mostly foreigners in 1983, but there were also Yugoslavs who, except in one case, did not want to reveal themselves to the public with their full names. ${ }^{28}$

In 1978, there were no more than 3,500 members of naturist societies in Yugoslavia. ${ }^{29}$ In 1985, the Naturist Society of Serbia may have had up to 900 members. ${ }^{30}$ In 1986, naturist societies in the Socialist Republic of Slovenia and the Socialist Republic of Croatia had a total of about

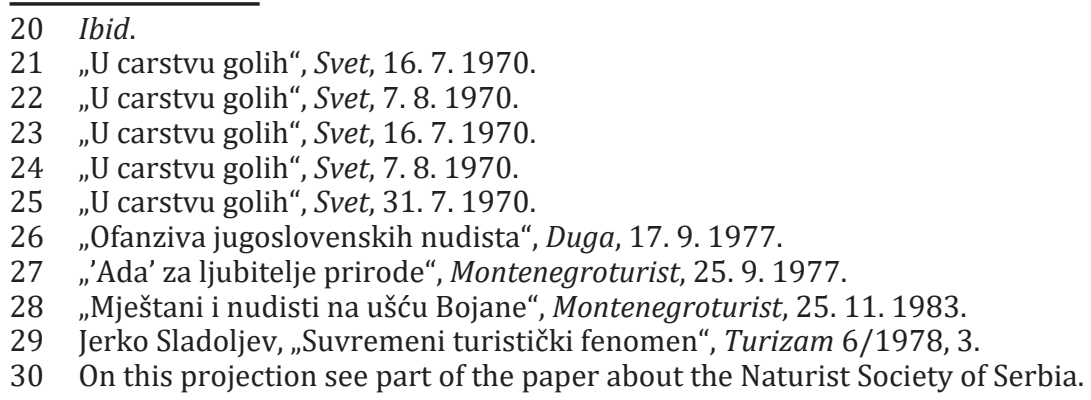


2,350 members (1,450 in Slovenia and 900 in Croatia).$^{31}$ Thus, in the middle of the eighties, there were around 3,250 members of Yugoslav naturist societies, which is slightly less than the number determined in 1978.

Undoubtedly, Yugoslav naturists (or nudists) were more numerous outside the membership of naturist organizations. For many, obviously, membership could have been a discretionary issue, and Yugoslav naturists most often did not want their identities to be known to others. At the same time, the lack of domestic guests in naturist camps was explained by the fact that the accommodation, for example in Ada Bojana, was more expensive than the usual hotel accommodation of the same category. ${ }^{32}$

In August of 1981, the Naturist Society of Croatia conducted a survey at the Kažela naturist camp in Medulin to see what the prospects were for the spread of naturism among Yugoslavs. Among the respondents, $87 \%$ were foreigners and $13 \%$ Yugoslavs, i.e. $9 \%$ were from Slovenia and $4 \%$ from Croatia. ${ }^{33}$ The capacity of Kažela was a total of 1,320 guests: 1,000 in the camp and 320 in the bungalows. ${ }^{34}$ So, there could have been about 160 Yugoslav naturists in Kažela at that time. In this regard, the interviewers of the Naturist Association of Croatia concluded that Yugoslavs, when they want to swim and sunbathe naked, "much more often" use wild beaches than naturist camps. ${ }^{35}$

Of the surveyed foreigners and locals in Kažela, 70\% were aged 26 to 55 , and $8 \%$ were younger than 26 . Twenty five percent of the respondents had higher education. Over $95 \%$ were not members of naturist societies, so the interviewers concluded that the respondents were nudists rather than naturists. When it comes to the surveyed Yugoslavs, all $100 \%$ of the respondents learned about naturism through the media, $67 \%$ expressed the desire to become members of naturist societies, and $83 \%$ said that there were few Yugoslav tourists who would become naturists. In this regard, conservatism was seen as a major obstacle to the development of Yugoslav naturist culture. ${ }^{36}$

In 1983 the Naturist Society of Croatia considered that the relationship in Yugoslav naturist centers, camps and wild beaches was even

31 „Društva naturista u Jugoslaviji“, Informacije Društva naturista Hrvatske, No. 12, (Zagreb, 1986).

32 „Ostrvo srećnih - jedan je od najatraktivnijih punktova na svijetu“, Montenegroturist, 25. 7. 1984.

33 Ivica Ružička, „Naturizam na naš način“, Turizam 1/1981, 19-20.

34 „Uspješan poslovni rezultat“, Arenaturist, 16. 4. 1981.

35 Ružička, „Naturizam na naš način“, 19-20.

36 Ibid., 19-20. 
more unfavorable than in Kažela, where in 1981 there were $87 \%$ foreign and $13 \%$ Yugoslav naturists. Namely, according to the assessment of this society, in 1983, more than $95 \%$ of foreigners and less than 5\% of Yugoslavs bathed and sunbathed at a very large number of naturist locations in Yugoslavia. ${ }^{37}$ However, if the number of 3,250 members of Yugoslav naturist societies in the mid-1980s was compared to 321,300 mostly foreign naturists a year in Yugoslavia, who spent their summers in organized capacities in the $1980 \mathrm{~s}$ - that is only $1 \%$.

By the way, among the foreign and domestic respondents in Kažela in 1981, most bathed and sunbathed naked due to health reasons, a sense of freedom and naturalness, equality and familiarity, and greater morals on naturist beaches. As many as $90 \%$ of the respondents were naturists only in summer, 55\% went only to organized camps, and $45 \%$ went to wild beaches. ${ }^{38}$ In 1977, Yugoslavs from various parts of the country claimed that they had become naturists exclusively for the sake of living a healthy life. ${ }^{39}$

Ivica Ružička, a radiology specialist and one of the leaders of the Naturist Society of Croatia, interpreted naturism in 1983 as healthy because the sun, water, air, and climate strengthen the body's defenses, encourage the recovery of a weakened organism, and raise the body's functional abilities. Ružička writes that a one-piece women's costume covers $30 \%$ of the body, precisely in the places where a woman is most biologically active, and the effect of sunbathing will be up to $50 \%$ weaker than the body that sunbathes naked. Bathing trunks cover $18 \%$ of the body, and the effect of sunbathing is a third weaker, about as weak as the effect of sunbathing in a bikini. The beneficial effects of sea water, which massages the body by swimming, are also weaker if the person is in a bathing suit as a barrier. Nakedness is considered more natural by naturists, it creates equality and natural sexuality, "and not introverted unhealthy eroticism" - Ružička concluded. ${ }^{40}$

However, from 1972, when the first two Yugoslav naturist societies were created, until the break-up of the Socialist Federal Republic of Yugoslavia in 1991/92, attempts to give Yugoslav naturism the form of an important social group or cultural movement remained on the sidelines. Yugoslav naturism was on the margins of the phenomenon of naturism in

37 „Uloga članova Društva naturista Hrvatske u društvenoj samozaštiti“, Bilten. Informativno glasilo Društva naturista Hrvatske, No. 2, (Zagreb), 1983.

38 Ružička, „Naturizam na naš način“, 19-20.

39 „Ofanziva jugoslovenskih nudista“, Duga, 17. 9. 1977.

40 Ivica Ružička, „Zdravi vidovi naturizma“, Turizam 5/1983, 19-20. 
Yugoslavia that was created through the interaction of Western naturists and the rich hotel and catering offer available to them. ${ }^{41}$

\section{Koversada Naturist Society and Naturist Organization of Yugoslavia}

The Society of the Friends of Koversada was founded on May 27, 1972. The head of that association was naturist Rexhep Tofani from Ljubljana, and the general secretary was tourist activist Jerko Sladoljev from Vrsar. ${ }^{42}$ At the beginning of June 1972, the founding congress of the Naturist Organization of Yugoslavia was held at Solaris naturist camp, headed by Vladimir Novak, a journalist from Zagreb. ${ }^{43}$ The Society of the Friends of Koversada had previously requested that it represent Yugoslav naturists at the International Naturist Federation. Few Yugoslav naturists argued over which of the naturist camps had the advantage: Koversada in Vrsar or Solaris in Poreč. ${ }^{44}$

However, the Society of the Friends of Koversada was not admitted to the International Naturist Federation because it could not decide whether Yugoslavia should be represented by the Society of the Friends of Koversada or the Naturist Organization of Yugoslavia, which had been founded in Solaris. ${ }^{45}$ Therefore, at the Thirteenth Congress of the International Naturist Federation in Koversada (1972), the Society of the Friends of Koversada was present as the host. However, there was an empty seat behind the Yugoslav flag at the congress. ${ }^{46}$ Vladimir Novak even says that an Austrian was sitting behind the Yugoslav flag, as a correspondent of the International Naturist Federation. ${ }^{47}$

41 For more details about naturism in Yugoslavia see also: Jerko Sladoljev, Naturistički kampovi i naselja. Povijest, koncepcija, razvoj, (Pula: CASH, 2001); Predrag Bosić, „Naturizam u povijesti istarskog turizma 1960-1990“, Radionica za suvremenu povijest. Istraživanja diplomanata pulskog Sveučilišta 2011-2013, priredili Igor Duda, Anita Buhin, Igor Stanić, (Pula-Zagreb: Srednja Europa, 2013), 109-126; Aleksandar Raković, „Razvoj naturizma u Jugoslaviji na primeru Koversade (1961-1981)“, Tokovi istorije 2/2020, 233-257.

42 „Raj na čarobnom otoku, Koversada“, 26.6. 1986.

43 „Predsjedatelj nije bio gol“, Plavi vjesnik, 19. 6. 1972; Jerko Sladoljev, „40-godišnjica naturizma u Jugoslaviji“, Turizam 5/1974, 26.

44 „Predsjedatelj nije bio gol“, Plavi vjesnik, 19. 6. 1972.

45 Jerko Sladoljev, „14. kongres INF i naturističke organizacije u Jugoslaviji“, Turizam 10/1974, 18-19.

46 Ibid., 18-19.

47 Vlado Novak, „Jesmo li naturisti“, Turizam 6/1978, 7. 
In 1973, Koversada hosted the annual assembly of the Society of the Friends of Koversada and one of the topics was still the rivalry with Solaris over the supremacy in Yugoslav naturism. At that assembly, the Society of the Friends of Koversada was renamed the Koversada Naturist Society. In 1973, this society had about 180 members, ${ }^{48}$ mostly from Slovenia. ${ }^{49}$ In 1974, the Koversada Naturist Society already had about 300 members. ${ }^{50}$

An attempt to extend the work of the Naturist Organization of Yugoslavia to the entire country in 1974 within the Riviera hotel-tourist company or the Solaris naturist camp was not successful. Namely, the members of the board were indeed from all over the country, but there were no funds to organize their meetings. ${ }^{51}$ The problem with the Naturist Organization of Yugoslavia, based in Zagreb, was that it was not registered at all. ${ }^{52}$

Yugoslavia became a member of the International Naturist Federation at the Fourteenth Congress, held from August 5 to 8, 1974, at the Port Nature Naturist Center near the town of Cap d'Agde in France. On behalf of Yugoslavia, the Koversada Naturist Society was accepted as a member in 1974 as the umbrella organization of the Yugoslav naturists. However, unofficially, Rexhep Teofani attended the congress in France, but on behalf of the Naturist Society "Yugoslavia". No one was present on behalf of the Koversada Naturist Society. ${ }^{53}$ At the Second Annual Assembly of the Naturist Society "Yugoslavia" on March 23, 1975 in Dolenjske Toplice, the Koversada Naturist Society joined the Naturist Society "Yugoslavia". ${ }^{44}$

However, there were some disagreements later, when it comes to the naturist society that originated in Koversada. This can be seen in the media that were associated with this society and/or societies. Namely, the first naturist newspaper Vjesnik Društva naturista Koversada was published in 1973 and the editor-in-chief was Mak Veselko from Ljubljana. ${ }^{55}$ However, under the old name of that society - the Society of the Friends of Koversada - the first issue of the newspaper Koversada was published in 1976, at a time when the Koversada Naturist Society was already attached to the Naturist Society "Yugoslavia".

48 „Stop odjevenima!“, Studio, 21. 7. 1973; Sladoljev, „40-godišnjica naturizma u Jugoslaviji“, 26.

49 „Stop odjevenima!“, Studio, 21. 7. 1973.

50 Sladoljev, „14. kongres INF“, 18-19.

51 Novak, „Jesmo li naturisti“, 7.

52 Sladoljev, „14. kongres INF“, 18-19.

53 Ibid., 18-19; „Kronologija razvoja naturizma u nas“, Bilten. Informativno glasilo Društva naturista Hrvatske, No. 1, (Zagreb), 1982.

54 "Odslej bomo enotni“, Naturist, junij 1975.

55 Sladoljev, „40-godišnjica naturizma u Jugoslaviji“, 26. 
In any case, three issues of Koversada were published: 1 . Published by the Society of the Friends of Koversada on May 25, 1976, and the editor-in-chief was Rajko Tomašić; 2 . Published by the hotel and tourist company Anita on July 1, 1981 with editor-in-chief Ratko Batel; 3. Published by the naturist center Koversada on June 26, 1986, whose editor-in-chief was Armando Černulj. Koversada also had a German edition in 1976, and Koversada from 1981 and 1986 was published in one edition in four languages: Serbo-Croatian, German, English, and Italian. ${ }^{56}$

\section{Naturist Society "Yugoslavia"}

As there was confusion between the Koversada Naturist Society and the Naturist Organization of Yugoslavia, there was a need for an umbrella organization that would have a clearer Yugoslav character. Therefore, as the first president of the Koversada Naturist Society, Rexhep Tofani founded the Naturist Society "Yugoslavia" in 1973, with headquarters in Ljubljana. ${ }^{57}$ Vladimir Novak claims that Tofani was unauthorized on behalf of Yugoslavia at the Fourteenth Congress of the International Naturist Federation in $1974 .{ }^{58}$ However, unlike Novak's naturist association, both of Tofani's naturist associations - the Koversada Naturist Society and the Naturist Society "Yugoslavia" - were registered. ${ }^{59}$

Due to these confusions, Jerko Sladoljev believed in 1974 that the Tourist Association of Croatia should support the unification of the entire membership into a single naturist organization in Yugoslavia. That would also solve the problem of issuing membership cards of the International Naturist Federation to Yugoslav naturists.$^{60}$ However, in 1975, the Naturist Society "Yugoslavia" issued two membership cards: its own, and that of the International Naturist Federation. ${ }^{61}$

At the Second Annual Assembly of the Naturist Society "Yugoslavia" in Dolenjske Toplice on March 23, 1975, ${ }^{62}$ Rexhep Tofani, a native of Junik in Kosovo and Metohija, was re-elected as president. ${ }^{63}$ Then official

56 „Uz prvi broj 'Koversade““, Koversada, 25. 5. 1976; „Dragi čitaoci!“, Koversada, 1. 5. 1981. See also: Koversada, 26. 6. 1986.

57 Sladoljev, „14. kongres INF“, 18-19; „Kronologija razvoja naturizma u nas“, Bilten. Informativno glasilo Društva naturista Hrvatske, No. 1, (Zagreb), 1982.

58 Novak, „Jesmo li naturisti“, 7.

59 Sladoljev, „14. kongres INF“, 18-19.

60 Ibid., 18-19.

61 „Poravnajte članarino“, Naturist, junij 1975.

62 „Odslej bomo enotni“, Naturist, junij 1975.

63 „Naturizem je oplemeniteni nudizem“, Naturist, junij 1975. 
organ Naturist was launched. ${ }^{64}$ In June of 1975, the first issue of Naturist was published as a newsletter of the Naturist Society "Yugoslavia". Naturist was printed with mimeograph machines in the Slovenian language. The newsletter served to implement the society's program outlined in its statute, to achieve a better organization and circulation of information, to popularize the work of the society among its members and the wider community, and to popularize naturist principles and nurture the spirit of naturism. ${ }^{65}$

The Naturist Society "Yugoslavia" writes about it: "Since naturism is in the initial phase of its development, one of the newsletter's purposes is to dedicate itself and further develop the theoretical foundations, place, role, and tasks of the naturist movement in our self-governing socialist society." ${ }^{66}$ At the annual assembly in 1975, the Naturist Society "Yugoslavia" emphasized that the naturist movement was "not in conflict with socialist morality," and so "we must bring our thought among the workers, to the broadest strata of the people." Members of the Naturist Society "Yugoslavia" addressed each other as "comrades." ${ }^{\prime 67}$

From the autumn of 1975, the Atlas travel agency ceded its premises in Ljubljana, whenever necessary, for meetings of the Naturist Society "Yugoslavia". ${ }^{6}$ This society worked on a voluntary basis, and therefore work on publishing Naturist was also voluntary. In the first issue, the editor of Naturist, Miklavž Knez, called on Yugoslav naturists to send texts to help publish the newsletter, send illustrations, and help reproduce and disseminate this newsletter. The membership fee of the Naturist Society "Yugoslavia" was used for publishing the newsletter. ${ }^{69}$

The Third Annual Assembly of the Naturist Society "Yugoslavia" was held on March 28, 1976 in Dolenjske Toplice, and 80 members participated. ${ }^{70}$ Members of the Naturist Society "Yugoslavia" were from all over Slovenia: Ljubljana, Kranj, Koper, Tržič, Radovljica, Škofja Loka and elsewhere. ${ }^{71}$ Most members were in Ljubljana, then in Celje. ${ }^{72}$ At the end of

64 „Iz našega programa dela“, Naturist, junij 1975.

65 „Prvi števliki našega glasila na pot", Naturist, junij 1975.

66 „Temeljno vsebinsko zasnovo glasila 'Naturist" , Naturist, junij 1975.

67 "Odslej bomo enotni“, Naturist, junij 1975.

68 „Včlanjevanje“, Naturist, junij 1976.

69 "Prvi števliki našega glasila na pot", Naturist, junij 1975.

70 „Štiri glavne naloge“, Naturist, junij 1976.

71 „Podružnice“, Naturist, december 1976; „Podružnica tudi na Gorenjskem“, Naturist, december 1976.

72 „Sekcije“, Naturist, junij 1976. 
1976, the Naturist Society "Yugoslavia" had 500 members. ${ }^{73}$ At the end of 1976 and the beginning of 1977, it managed to enable its members winter recreational swimming at the "Stern" spa in Ježica (Ljubljana) and in the Golf Hotel in Bled. ${ }^{74}$

The program of the Naturist Society "Yugoslavia" for 1976 determined the method of membership, intentions to organize naturist beaches and spaces in Slovenia, establish sections by places, recreation and activities outside the summer season, publishing Naturist newsletter, popularizing naturism and informing the general public, cooperation with related societies and organizations that are considered sports organizations and societies for environmental protection, cooperation with naturist beaches and camps, and cooperation with the International Naturist Federation and related organizations abroad. ${ }^{75}$

In this regard, the Naturist Society "Yugoslavia" was involved in 1976 in topics related to nature protection. That is how Rexhep Tofani spoke at the symposium in Budva "Nature protection and tourism," and the society joined the Association for Environmental Protection of the Socialist Republic of Slovenia. ${ }^{76}$ By expanding the network, through the local sections, the Naturist Society "Yugoslavia" intended to show that "they are not sexual apostates, but completely normal people."77

The Naturist Society "Yugoslavia" had the ambition to organize a big meeting of all Yugoslav, Austrian, and Italian naturist associations. In this regard, the traditional meeting of naturists of the three countries, the fifth in a row, was held on May 22 and 23, 1976 in Valalta camp in Rovinj. The meeting was attended by the Naturist Society "Yugoslavia" and the naturist association Wörthersee from Klagenfurt in Austria and Liburnia from Trieste. The gathering included 184 naturists: 106 from Yugoslavia, 46 from Klagenfurt, and 32 from Trieste. ${ }^{78}$ The Naturist Society "Yugoslavia" also participated at the Fifteenth Congress of the International Naturist Federation, which was held on the naturist island near Mainz (July 31 - August 6, 1976). At the congress organized by the Naturist Associ-

\footnotetext{
73 „Pred ustanovitvijo novih društev naturistov“, Naturist, december 1976.

74 „Vabimo vas na rekreacijsko plavanje k Šternu“, Naturist, december 1976; „,Rekreacijsko plavanje za naturiste tudi na Bledu“, Naturist, december 1976.

75 „Program dela Društva naturistov 'Jugoslavija' v letu 1976“, Naturist, junij 1976.

76 „Udeležba na raznih srečanjih“, Naturist, december 1976.

77 „Sekcije“, Naturist, junij 1976.

78 „Nad 100 naših članov“, Naturist, junij 1976.
} 
ation of the Federal Republic of Germany, 40 flags of the members of the naturist federation were displayed, including the one from Yugoslavia. ${ }^{79}$

The Naturist Society "Yugoslavia", which mainly included Slovenian naturists, was disbanded in 1976 into sections. ${ }^{80}$ It published three issues of Naturist in mimeographed form: in June of 1975, in June of 1976, and in December of 1976. The editor-in-chief of all three issues was Miklavž Knez.

\section{Association of Naturist Societies of Slovenia}

Sections of the Naturist Society "Yugoslavia" split up into separate naturist societies. Since 1977, the Gorenjska Naturist Society from Kranj was headed by Vladimir Lah; the K naravi (Back to Nature) Naturist Society from Ljubljana was headed by Miklavž Knez, the Obala Naturist Society from Koper was headed by Nina Potočnik, the Venus Naturist Society from Celje was headed by Stane Smrečnik. ${ }^{81}$ In 1979, the Slovenian Naturist Societies founded the Association of Slovenian Naturist Societies, with headquarters in Kranj, headed by Vladimir Lah. ${ }^{82}$

The seventh international meeting of naturists from Yugoslavia, Austria, and Italy was held at Solaris from May 26 to 28, 1978. Six Yugoslav societies participated: Obala from Koper, Venus from Celje, K naravi from Ljubljana, Gorenjska from Kranj, the Naturist Society of Croatia from Zagreb, and the Naturist Society of Serbia from Belgrade. Wörthersee from Klagenfurt and Liburnia from Trieste also took part. The meeting was attended by 120 people and also included representatives of the International Naturist Federation. The main topic was the suppression of wild naturist beaches and its negative affect on the Yugoslav economy. ${ }^{83}$

The Slovenian naturist societies continued with the plans of the former Naturist Society "Yugoslavia" to establish naturist camps in spas, rivers and lakes in the continental parts of Slovenia and Yugoslavia. In this regard, in Banovci near Ljutomer in northeastern Slovenia, in 1985, there was a naturist camp at the thermal baths. ${ }^{84}$ In 1985 , naturists also gathered

79 „15. kongres mednarodne federacije naturistov“, Naturist, december 1976.

80 „Kronologija razvoja naturizma u nas“, Bilten. Informativno glasilo Društva naturista Hrvatske, No. 1, (Zagreb), 1982.

81 Ibid.

82 Ibid.

83 „Sedmi međunarodni susret naturista Solaris 26-28 V 1978“, Naš glas, lipanj 1978.

84 „Cijene“, Informacije Društva naturista Hrvatske, broj 5, (Zagreb), travanj 1985; „Poslovnost“, Informacije Društva naturista Hrvatske, No. 6-7, svibanj-lipanj 1985. 
at the Dobrna Spa near Celje. ${ }^{85}$ The naturist camp in Čateške Toplice in Slovenia, not far from the border with Croatia, was opened on May 1, 1986 and consisted of about a hundred camping units, two pools with thermal water, one of which was intended for children, a toilet, a shop, some other catering facilities, and sports and recreational fields and playgrounds for children. ${ }^{86}$ The Gorenjska Naturist Society from Kranj opened a naturist camp called Smlednik in Dragočajna on the Sava River, near Medvode, not far from Ljubljana, on August 30, 1986. ${ }^{87}$

The Naturist Society of Croatia published a list that showed that Slovenian naturist societies and members were the most numerous in 1986, and included new local societies: The Venus Naturist Society in Celje, had about 500 members and gathered in the summer on the Savinja River and once a month in the winter at the Dobrne pool and sauna; The Gorenjska Naturist Society in Kranj, with about 350 members, gathered in the Smlednik naturist camp on the Sava River, and in winter they got together every other Saturday at the pool of the Park Hotel; The K naravi Naturist Society from Ljubljana, with about 200 members, gathered in the summer on the Sava River, and in the winter they assembled every Wednesday at the pool of the School of Physical Education, and every Thursday in the sauna of that school; the Mariborski otok Naturist Society, with 250 members, gathered on the beach on the Maribor island on the Drava River, and in the winter on Fridays at the pool in Ptujske Toplice; the Pomurje Naturist Society in Radenci, with about 150 members, gathered in the spa and Banovci naturist camp; The Naturist Society of Slavonija and Baranja from Osijek in Croatia, with 250 members, gathered on the Island of Love on the Drava River, and once a month in the winter in the pool of the Junaković Spa near Apatin in Serbia; the Naturist Society of Croatia from Zagreb, with about 650 members, gathered in the summer at Rakitje Lake near Zagreb, and in the winter every Saturday in the pool of the Terme Hotel a tthe Čateške Toplice spa center. ${ }^{88}$

Thus, the societies that made up the Association of Naturist Societies of Slovenia had about 1,450 members, and the two societies in Croatia had about 900 members. The Naturist Society of Serbia is not even mentioned on that list. ${ }^{89}$ By the way, on March 14, 1986, the first collegium of

85 „Bio sam gost“, Informacije Društva naturista Hrvatske, No. 6-7, svibanj-lipanj 1985.

86 „FKK camp u Čateškim Toplicama“, Informacije Društva naturista Hrvatske, broj 8, prosinac 1985.

87 „Smlednik“, Zdravo, No. 13, (Zagreb), 1986.

88 „Društva naturista u Jugoslaviji“, Informacije Društva naturista Hrvatske, No. 12, 1986.

89 Ibid. 
presidents of the Yugoslav naturist societies was held in Celje, which included only societies from Croatia and Slovenia. ${ }^{90}$

In 1986, naturist societies from Kranj and Ljubljana organized meetings at the lakeside resort of Bled for about 200 naturists from Yugoslavia, Austria, and Italy. ${ }^{91}$ About 200 naturists from Kranj, Ljubljana, Maribor, Celje, Karlovac, Zagreb, Klagenfurt, and Graz gathered from 13 to 15 February 1987 at the Tuheljske Toplice in the Croatian Zagorje region, for the First Winter International Naturist Conference held in Yugoslavia. ${ }^{92}$

\section{Naturist Society of Croatia and Naturist Society of Slavonia and Baranja}

When it comes to the continental part of Croatia, people from Zagreb bathed naked illegally in the Sava River in $1973 .{ }^{93}$ From this field of disorganization, the Zagreb naturists stepped into creating an organization that was the strongest in Yugoslavia in terms of activities. In this regard, the founding assembly of the Zagreb-based Naturist Society of Croatia was held on June 2,1977, and Vladimir Novak was elected as president. ${ }^{94}$ This naturist association was, therefore, a kind of offshoot of the Naturist Organization of Yugoslavia.

The goals of the Naturist Society of Croatia were to "improve and strengthen physical and social health in a wholesome social community, using natural factors; promote and implement organized naturist tourism; use benefits provided to members by membership in the Naturist Society of Croatia, on numerous naturist beaches throughout our country; promote social activity of members throughout the year."95

On October 30,1982, the Naturist Society of Croatia held its regular annual assembly. ${ }^{96}$ At that time, the head of the Naturist Society of Croatia was Mladen Konjević. In addition to about 40 delegates, the annual assembly was attended by representatives of the Tourist Association of Croatia and the Zagreb Tourist Board. The Naturist Society of Croatia,

90 „Dogovor", Informacije Društva naturista Hrvatske, No. 11, 1986.

91 „Godina 1986“, Zdravo, No. 13, 1986.

92 "Tuheljske toplice postaju zimski naturistički centar“, Zdravo, No. 14, 1987.

93 „Stop odjevenima!“, Studio, 21. 7. 1973.

94 „Kronologija razvoja naturizma u nas“, Bilten. Informativno glasilo Društva naturista Hrvatske, No. 1, 1982.

95 „Prijatelji naturizma“, Bilten. Informativno glasilo Društva naturista Hrvatske, No. 1, 1982.

96 „Rezervirano za uredništvo“, Bilten. Informativno glasilo Društva naturista Hrvatske, No. 2, 1983. 
they say, cooperated successfully with the Tourist Association of Croatia and the Group for Camping and Naturism at the General Board of the Tourist Economy of Yugoslavia, especially with the president of the group, Jerko Sladoljev. ${ }^{97}$

The Group for Camping and Naturism at the General Board of the Tourist Economy within the Yugoslav Chamber of Commerce was founded in 1981 and had a Naturism Committee. ${ }^{98}$ The task of the Group for Camping and Naturism was in 1989 to "perform more strongly" in foreign markets, ${ }^{99}$ and in 1990 the activity of this group was directed abroad. ${ }^{100}$ It seems, therefore, that the good cooperation of the Naturist Society of Croatia with the Group for Camping and Naturism could have been of a friendly nature in the first place.

The Naturist Society of Croatia also cooperated with the Coordination Committee for Social Organizations and Citizens' Associations of the Socialist Alliance of the Working People of the Socialist Republic of Croatia (SSRN Hrvatske), which assessed favorably the statutory suitability of the Naturist Society of Croatia. ${ }^{101}$ In addition, the Naturist Society of Croatia established cooperation with the Association of Naturist Societies of Slovenia and the Naturist Society of Serbia in order to resolve issues and spread the naturist movement in Yugoslavia. These associations and societies formed the initiative committee for the establishment of the Yugoslav Naturist Association. The Naturist Society of Croatia was active in the Alpe-Adrija (Alps-Adria) naturist cooperation, and used the press, radio stations, and other means to promote naturism. ${ }^{102}$

In 1982, the Naturist Society of Croatia had only 11 members, and in 1983 the number increased to about $100 .{ }^{103}$ In 1984, the Naturist Society of Croatia had over 500 members, of which about 400 with paid

97 „Obavijest o radu Društva naturista Hrvatske“, Bilten. Informativno glasilo Društva naturista Hrvatske, No. 2, 1983.

98 „Drugi put za popravni“, Turističke novine, 11. 8. 1988.

99 AJ, Tourist Association of Yugoslavia, Fond 746, Box 220, Agenda for 1989 of the General Board of the Tourist Economy within the Yugoslav Chamber of Commerce (Program rada Udruženja turističke privrede za 1989. godinu).

100 AJ, Tourist Association of Yugoslavia, Fond 746, Box 221, Agenda for 1990 of the General Board of the Tourist Economy within the Yugoslav Chamber of Commerce (Program rada Udruženja turističke privrede za 1990. godinu).

101 „Obavijest o radu Društva naturista Hrvatske“, Bilten. Informativno glasilo Društva naturista Hrvatske, No. 2, 1983.

102 Ibid.

103 Ibid. 
membership fees, ${ }^{104}$ and in 1986 at one point it had exactly 598, ${ }^{105}$ and then about 650 members. ${ }^{106}$ In five years, the membership in the Naturist Society of Croatia increased by about 60 times, but the number was still small, because the "biggest obstacle to the faster influx of more new members were prejudices within the local community." The Naturist Society of Croatia also worked on a volunteer basis. Members called each other "comrades."107

In 1983, the Naturist Society of Croatia planned to open naturist beaches and camps in Zagreb and on the Kupa River near Ozalj for some of its goals. In addition, they advocated for membership to be the bearer of national defense and social self-protection in their communities. ${ }^{108}$ The Zagreb Tourist Board proposed that naturist camps be opened in Tuheljske Toplice, on the Sava and elsewhere. ${ }^{109}$

In 1983, the members of the Naturist Society of Croatia had organized camping on the lakes in the village of Rakitje near Zagreb, where, after some strife, a "peaceful coexistence" was established with campers in bathing suits. ${ }^{110}$ The local community of Rakitje gave its consent for the naturists to gather at the lakes where they did not interfere with the other activities. However, in 1986, the Naturist Society of Croatia fought to completely legalize the area in Rakitje and adapt it to naturist recreational needs as a special zone. ${ }^{111}$ Since February of 1984, the Naturist Society of Croatia organized gatherings and recreational activities at the Terme Hotel in Čateške Toplice, with a swimming pool, a sauna, and a tanning salon. ${ }^{112}$ The annual assembly of the Naturist Society of Croatia was held on February 23, 1985 at the Čateške Toplice spa center. ${ }^{113}$

104 „Članstvo“, Informacije Društva naturista Hrvatske, No. 3, 20. 12. 1984.

105 „Društvo naturista - šta je to?", Zdravo, No. 14, 1987.

106 „Društva naturista u Jugoslaviji“, Informacije Društva naturista Hrvatske, No. 12, 1986.

107 „Obavijest o radu Društva naturista Hrvatske“, Bilten. Informativno glasilo Društva naturista Hrvatske, No. 2, 1983.

108 „Program rada Izvršnog odbora za razdoblje 1982/83“, Bilten. Informativno glasilo Društva naturista Hrvatske, No. 2, 1983.

109 „Diskusija“, Bilten. Informativno glasilo Društva naturista Hrvatske, No. 2, 1983.

110 „Godišnja skupština društva naturista Hrvatske“, Informacije Društva naturista Hrvatske, No. 4, 24. 3. 1985; „Između dvije skupštine“, Informacije Društva naturista Hrvatske, No. 8, 12.1985

111 „Rakitje“, Informacije Društva naturista Hrvatske, No. 9, siječanj 1986.

112 „Rekreacija u bazenu hotela 'Terme' u Čatežu“, Informacije Društva naturista Hrvatske, No. 3, Zagreb, 20.12. 1984.

113 Godišnja skupština društva naturista Hrvatske, Informacije Društva naturista Hrvatske, No. 4, 24. 3. 1985. 
Meetings of naturists that were part of the Alps-Adria cooperation were always held in the pre-season in one of the Istrian naturist summer resorts. The Alps-Adria naturist cooperation expanded the already established cooperation of Yugoslav naturists with naturists from Klagenfurt and Trieste, to include the wider area of Austria and Italy, then the Federal Republic of Germany, and later Hungary. A meeting of about 240 naturists from the Federal Republic of Germany, Austria, Italy, Slovenia, and Croatia was held at the Solaris camp in Poreč from June 1-3, 1984, and the organizer was the Naturist Society of Austria. ${ }^{114}$

The following year, the Naturist Society of Croatia and the Association of Slovenian Naturist Societies organized the Alps-Adria naturist convention at the Monsena naturist resort in Rovinj from 17 to 19 May 1985. ${ }^{115}$ The Naturist Society of Croatia also organized Alps-Adria naturist meetings at Monsena from May 29 to June 1, 1986. ${ }^{116}$ Around 774 naturists from 24 societies gathered at that fourth Alps-Adria naturist meeting in 1986 at Monsena with members from the FR of Germany, Austria, Italy, Hungary, and Yugoslavia. The participants also entrusted the Naturist Society of Croatia with organizing the fifth Alps-Adriatic naturist meeting (May 23-31, 1987). ${ }^{117}$ Yugoslavia's Atlas Travel Agency from Dubrovnik organized a cruise through Istria and the Kvarner Bay in May of 1987 for interested participants in the Alps-Adria naturist meeting at Monsena. ${ }^{118}$

A Roundtable on Naturism was held in Zagreb on November 8, 1986, organized by the Naturist Society of Croatia, the Tourist Association of Sroatia and the Zagreb International Fair. Representatives of naturists from Yugoslavia, Austria, Bavaria, and Italy were present at the gathering, but no economic organization that earned income through business cooperation with naturists participated. It was underlined at the meeting that Yugoslav naturist centers had no special interest in Yugoslav na-

114 „Godišnja skupština društva naturista Hrvatske“, Informacije Društva naturista Hrvatske, No. 4, 24. 3. 1985; „13. susret naturista Alpe-Jadran '85“, Informacije Društva naturista Hrvatske, No. 4, 24. 3. 1985.

115 „Godišnja skupština društva naturista Hrvatske“, Informacije Društva naturista Hrvatske, No. 4, 24. 3. 1985; „13. susret naturista Alpe-Jadran '85“, Informacije Društva naturista Hrvatske, No. 4, 24. 3. 1985.

116 „Die IV. begegnung Alpe-Adria“, Informacije Društva naturista Hrvatske, No. 10, 1986.

117 „Godina 1986“, Zdravo, No. 13, (Zagreb), 1986.

118 „Krstarenje za naturiste“, Zdravo, No. 13, 1986. 
turists. ${ }^{119}$ The next Roundtable on Naturism was held from November 20 to 22, 1987 in Tuheljske Toplice. ${ }^{120}$

At the end of 1986, the Naturist Society of Croatia had 598 registered members. Most of them were between 30 and 39 years old (38.9\%), followed by 40 to $49(18.9 \%), 20$ to $29(14.8 \%)$, under $20(12 \%)$, and older than 50 years $(15.4 \%)$. About $60 \%$ of the members were family people and about $40 \%$ were single. About 250 members were women and about 350 were men. In addition to the citizens of the Socialist Republic of Croatia, the membership of the Naturist Society of Croatia included 11 citizens of the Socialist Republic of Bosnia-Herzegovina, 11 citizens of the Socialist Republic of Serbia, 3 from the Socialist Republic of Slovenia, 2 from the Socialist Republic of Macedonia, and 4 members from abroad. In this regard, the Naturist Society of Croatia considered itself as a "Yugoslav society."

Among the members of the Naturist Society of Croatia, 374 were employed in the social sector, 42 in the private sector, there were 34 pensioners, 91 children, pupils, and students, 3 members worked in foreign companies, and 18 were miscellaneous. Furthermore, the membership included 3 doctors of science, 4 masters, 153 members with higher education, 20 with higher education, 152 with secondary education, 1 with lower education, 52 members were highly qualified workers, 58 skilled workers, 2 unskilled workers. 63 members worked in science, culture and education, 44 members in administration and services, 39 members in health care, 38 members in the electrical industry, electricity distribution and related professions, 33 members in the metal and machine industry, 31 members in traffic, communications and trade, 24 members in design and construction, 22 members in the chemical industry, 21 members in the food industry, 15 members in banking, 13 members in textile industry, 12 members in paper processing and graphic activity, 10 members in journalism, 8 members in catering and tourism, in leather processing 7 members, in forestry and wood processing 5 members. ${ }^{122}$

In March of 1984, the Naturist Society of Slavonia and Baranja was founded, with its headquarters in Osijek, headed by Boris Čubrilo. ${ }^{123}$ Members of the Naturist Society of Slavonia and Baranja gathered in 1985

119 „Nešto novo u naturizmu“, Zdravo, No. 13, 1986.

120 „Najveći regionalni okrugli stol o naturizmu“, Zdravo, No. 14, 1987.

121 „Društvo naturista - šta je to?“, Zdravo, No. 14, 1987.

122 Ibid.

123 „Godišnja skupština udruženja naturista Slavonije i Baranje“, Informacije Društva naturista Hrvatske, No. 3, 20.12. 1984. 
at the Junaković Bay near Apatin. ${ }^{124}$ The Naturist Society of Slavonia and Baranja had about 250 members in 1986, ${ }^{125}$ and at the end of that year, it received the use of the pool in the Čelarevo Spa near Novi Sad every other Saturday. ${ }^{126}$ Naturists from Osijek gathered on the Island of Love on the Drava River, the only registered naturist beach in the continental part of Yugoslavia. ${ }^{127}$ In 1986, another naturist society in the FR of Croatia was founded in Karlovac. ${ }^{128}$

At the annual assembly of the Naturist Society of Slavonia and Baranja on December 2, 1984, a conflict broke out between Dragan Čolaković, who headed the Naturist Society of Serbia, on the one hand, and Mladen Noršić, the president of the Naturist Society of Croatia and Tone Filipič, the head of the Association of Naturist Societies of Slovenia, on the other, over the concept of the naturist movement in Yugoslavia. After that, the Naturist Society of Croatia and the Association of Naturist Societies of Slovenia agreed to further coordinate their activities. ${ }^{129}$ These two naturist organizations further decided to ignore the Naturist Society of Serbia. In December of 1984, Noršić and Filipič discussed the launch of a joint naturist newsletter in Croatia and Slovenia. ${ }^{130}$

Until that time, the Naturist Society of Croatia had been publishing its Bulletin in mimeograph form (two annual issues: 1982 and 1983), then the newspaper Informacija (eight issues and one double issue: from December 20, 1984 to the spring of 1986) and finally the newspaper Zdravo with the subtitle Naturist Societies of Yugoslavia (two annual issues: 1986 and 1987) in which they followed the naturist lifestyle only in Croatia and Slovenia. The name Zdravo means "healthy living" (Zdravo also means hello) as a feature of the naturist movement. ${ }^{131}$ Between the Bulletin, Information and Zdravo, the numbering is continuous (1-14). The editors of the Bulletin were Ivica Ružička and Mladen Konjević, the editor-in-chief or the editor of the Information and Zdravo bulletins were not mentioned, but they the publisher was signed as Mladen Noršić.

124 „Nedoumica“, Informacije Društva naturista Hrvatske, No. 6-7, svibanj-lipanj 1985.

125 „Društva naturista u Jugoslaviji“, Informacije Društva naturista Hrvatske, No. 12, 1986.

126 „Nešto novo u naturizmu“, Zdravo, No. 13, 1986.

127 „Novosti iz rada udruženja naturista Slavonije i Baranje“, Informacije Društva naturista Hrvatske, No. 12, 1986.

128 „Godina 1986“, Zdravo, No. 13, 1986.

129 „Godišnja skupština udruženja naturista Slavonije i Baranje“, Informacije Društva naturista Hrvatske, No. 3, 20.12.1984.

130 „Imali smo gosta“, Informacije Društva naturista Hrvatske, No. 3, 20. 12. 1984.

131 „Zdravo“, Zdravo, No. 13, 1986. 


\section{Naturists Society of Serbia and Naturist Society "Ada"}

The Naturist Society of Serbia, with its headquarters in Belgrade, was founded in 1977 and was headed by Dragan Čolaković. ${ }^{132}$ In 1977, the Belgrade naturists were present on the Small War Island, also called the Island of Horses, in an armlet of the Danube between the Great War Island and the Ušće, where the Sava River flows into the Danube. ${ }^{133}$ In 1979, they asked for some space on the river island of Ada Ciganlija, but they did not get it officially. ${ }^{134}$ As a matter of fact, the Belgrade naturists have been pushed further and further toward the edge of Ada Ciganlija from year to year. The behavior on the naturist part of Ada Ciganlija was regulated by "unwritten rules." 135

At the annual assembly of the Naturist Society of Slavonia and Baranja on December 2, 1984, Čolaković clashed with Noršić and Filipič. Čolaković believed that the ideology of naturism should be spread in public, and not basically act through gatherings in naturist societies. According to Čolaković, travel agencies and caterers who would have financial interests would take better care of the activities and needs of naturists. Čolaković said that he had agreed with Borba daily to publish magazine Naturist, which would be sold at newsstands. ${ }^{136}$

Noršić and Filipić insisted on naturist associations, they were against travel agencies and caterers taking care of the needs of naturists; they said that the focus in naturism should be on the family, without insisting at all costs on increasing numbers, adding that it was especially wrong to publish a naturist magazine that would promote nudity at newsstands because naturists would be the last persons to buy that newspaper. Therefore, they were against publishing a naturist magazine that would be sold publicly, but they were in favor of such a newspaper being printed only for naturists. ${ }^{137}$

At the end, Naturist, which Čolaković had imagined, was not even launched. Therefore, there is no reliable information on the membership of the Naturist Society of Serbia. However, Montenegroturist announced in 1985 that the percentage of registered naturists in the Socialist Repub-

132 „Kronologija razvoja naturizma u nas“, Bilten. Informativno glasilo Društva naturista Hrvatske, No. 1, 1982.

133 „Ofanziva jugoslovenskih nudista“, Duga, 17. 9. 1977.

134 „Vreme golih”, Duga, 21. 6. 1980.

135 „Celo telo izloženu suncu“, Ilustrovana politika, 26. 7. 1997.

136 „Godišnja skupština udruženja naturista Slavonije i Baranje“, Informacije Društva naturista Hrvatske, No. 3, 20.12. 1984.

137 Ibid. 
lic of Serbia was only "three per mill" lower than in the Socialist Republic of Croatia, ${ }^{138}$ which suggests that the number of members of the Naturist Society of Serbia could be up to around 900.

In 1989, Čolaković was still the head of the Naturist Society of Serbia. At the same time, the Naturist Society "Ada" from Belgrade, headed by Valerija Markulin, was also active. In in September of 1989, the Naturist Society "Ada", together with the Tourist Board of the Municipality of Bela Crkva, the Banat Company, and Vojvodinaturist organized the first naturist caravan from Belgrade to one of the lakes where the municipality of Bela Crkva opened the first naturist camp in Serbia. At the entrance to the camp, there was a sign with the inscription "Naturist Society of Serbia. The Naturist Coast." ${ }^{139}$ In 1985, naturists also gathered at Lake Palić near Subotica, ${ }^{140}$ but that naturist beach was soon closed down. ${ }^{141}$

\section{Conclusion}

Yugoslav naturist societies expressed their intention to be of social benefit to the self-government community of socialist Yugoslavia in the spheres of physical and health culture, environmental protection, tourist propaganda, public defense, and social self-protection. However, these ambitions of theirs were only approved marginally by the Yugoslav public, and Yugoslav naturist societies did not achieve sufficient enough numbers the quantity of members to produce quality. According to the Yugoslav naturists, there were certainly prejudices in the local communities, and even those Yugoslavs inclined to naturism did not hear about it from domestic naturist societies but were informed about that phenomenon on the Adriatic coast from the media.

In this regard, in the period from 1972 to 1991,Yugoslav naturist societies remained on the very sidelines of the phenomenon of naturism in Yugoslavia, which was shaped by foreign naturists, the Yugoslav hotel and catering industry on the sunny Adriatic, and tolerance of nudity in a socialist society. Even naturist camps on Yugoslavia's Adriatic coast were not interested in domestic naturists because their favorite guests were foreigners who brought in foreign currency profits. Therefore, Yugoslav

138 „Izdašni poklonici Evinog kostima“, Montenegroturist, 25. 8. 1985.

139 „Nudistički kamp na jezeru pored Bele Crkve“, Nudizam.com, accessed 3 April 2020.

140 „Naturizam u krizi!?“, Informacije Društva naturista Hrvatske, No. 8, prosinac 1985.

141 „Nudistički kamp na jezeru pored Bele Crkve“, Nudizam.com, accessed 3 April 2020. 
naturists failed to create any form, or important social group, or cultural movement.

Yugoslav naturist societies had the most success in spreading naturist ideas in the continental parts of Yugoslavia, where they gathered on rivers, lakes, spas, and swimming pools, and the culmination of these activities was the opening of official naturist camps and beaches in those parts of the country. There was some success in the meetings organized by Yugoslav naturist societies in order to socialize with Austrian, Italian, and also West German and Hungarian naturists, and even though this had some significance for them, it had no social significance that would benefit Yugoslavia.

\section{Sources and Literature}

- $\quad$ Arhiv Jugoslavije. Turistički savez Jugoslavije, Fond 746: kutija 107, Katalog Camping '89 Jugoslavija, Beograd: Turistički savez Jugoslavije, Auto-moto savez Jugoslavije, 1989; kutija 220, Program rada Udruženja turističke privrede za 1989. godinu; kutija 221, Program rada Udruženja turističke privrede za 1990. godinu.

- $\quad$ Bosić, Predrag. „Naturizam u povijesti istarskog turizma 1960-1990“. Radionica za suvremenu povijest. Istraživanja diplomanata pulskog Sveučilišta 2011-2013, priredili Igor Duda, Anita Buhin, Igor Stanić, 109-126. Pula-Zagreb: Srednja Europa, 2013,

- Harp, Stephen L. Au Naturel. Naturism, Nudism, and Tourism in Twentieth-Century France. Baton Rouge: Louisiana State University Press, 2014.

- Hoffman, Brian. Naked: a Cultural History of American Nudism. New York: New York University Press, 2015.

- $\quad$ Marić, Savo. „Naturizam - nova šansa turizma“. Turizam, broj 5/1972, 27-28.

- $\quad$ Novak, Vlado. „Jesmo li naturisti“. Turizam 6/1978, 7.

- $\quad$ Pfitzner, Georg. Der Naturismus in Deutschland, Österreich und der Schweiz, Band 1. Hamburg-Altona: Richard Danehl's Verlag, 1964.

- Raković, Aleksandar. „Razvoj naturizma u Jugoslaviji na primeru Koversade (1961-1981)“. Tokovi istorije 2/2020, 233-257. doi: 10.31212/ tokovi.2020.2.rak.233-257

- Ružička, Ivica. „Naturizam na naš način“. Turizam 1/1981, 19-20.

- Ružička, Ivica. „Zdravi vidovi naturizma“. Turizam 5/1983, 19-20.

- Sladoljev, Jerko. „40-godišnjica naturizma u Jugoslaviji“. Turizam 5/1974, 25-27.

- Sladoljev, Jerko. „14. kongres INF i naturističke organizacije u Jugoslaviji“. Turizam 10/1974,18-20.

- $\quad$ Sladoljev, Jerko. „Suvremeni turistički fenomen“. Turizam 6/1978, 2-6. 
- $\quad$ Sladoljev, Jerko. Naturistički kampovi i naselja. Povijest, koncepcija, razvoj. Pula: CASH, 2001.

- $\quad$ Toepfer, Karl. Empire of Ecstasy. Nudity and Movement in German Body Culture, 1910-1935. Berkeley: University of California Press, 1997.

- Vugrinčić, Jelena. „Naturizam kao mnogostruka pozitivna pojava“. Turizam 7-8/1977, 39-40.

- $\quad$ Ilustrovana politika (Beograd)

- $\quad$ Montenegroturist (Budva)

- Svet (Beograd)

- $\quad$ Arenaturist (Pula)

- Duga (Beograd)

- $\quad$ Bilten. Informativno glasilo Društva naturista Hrvatske (Zagreb)

- Informacije Društva naturista Hrvatske (Zagreb)

- Jadran (Rovinj)

- Koversada (Vrsar)

- $\quad$ Našglas (Poreč)

- $\quad$ Naturist (Ljubljana)

- Plavi vjesnik (Zagreb)

- $\quad$ Studio (Zagreb)

- $\quad$ Turističke novine (Beograd)

- Turizam (Zagreb)

- $\quad$ Vikend (Zagreb)

- Zdravo (Zagreb)

- $\quad$ Nudizam. com (Beograd) 


\title{
Резиме
}

\author{
Александар Раковић
}

\section{Организације и делатност југословенских натуриста (1972-1991)}

\begin{abstract}
АПстРАкт: Рад приказује организацију и делатност југословенских натуриста, као и њихову намеру да у социјалистичком друштву од 1972. до 1991. имају друштвену улогу у пољу физичке и здравствене културе, заштите животне средине, туристичке пропаганде, општенародне одбране и друштвене самозаштите. Југословенске натуристичке организације, упркос амбицијама, нису формирале битну друштвену групу и културни покрет.

КљУчнЕ РЕчи: натуризам, социјализам, Југославија, организација, делатност, нагота
\end{abstract}

Југословенска натуристичка друштва исказивала су намеру да буду од друштвене користи за самоуправну заједницу у пољима физичке и здравствене културе, заштите животне средине, туристичке пропаганде, општенародне одбране и друштвене самозаштите. Међутим, за ове њихове амбиције само је узгредно било слуха у југословенској јавности, а натуристичка друштва нису постигла довољну бројност да би квантитет чланства дао и квалитет. Према југословенским натуристима извесно је у њиховим локалним срединама било предрасуда, а ни они Југословени склони натуризму нису о томе чули од домаћих натуристичких друштава већ су о тој појави на јадранској обали обавештени из средстава јавног информисања.

Стога су југословенска натуристичка друштва остала од 1972. до 1991. на самој маргини феномена натуризма у Југославији, који су обликовали инострани натуристи, југословенска хотелско-угоститељска понуда на сунчаном Јадрану и толеранција према наготи у социјалистичком друштву. Чак ни натуристички кампови на јадранској обали Југославије нису били заинтересовани за домаће натуристе јер су им дражи гости били странци који су доносили девизне приходе. Стога југословенски натуристи нису створили форму нити битне друштвене групе нити икакав културни покрет. 
Југословенска натуристичка друштва имала су највише успеха у ширењу натуристичких идеја по континенталним деловима Југославије, где су се окупљали на рекама, језерима, бањама и базенима, да би врхунац тих активности било отварање званичних натуристичких кампова и плажа у тим деловима земље. Успехом се могу оценити и скупови које су југословенска натуристичка друштва организовала ради дружења са аустријским, италијанским, а потом и са западнонемачким и мађарским натуристима, али то је имало значај за њих а не и друштвену важност од које би било користи за Југославију. 